\title{
Regulation of Hormone-sensitive Calcium Influx by the Adenylyl Cyclase System in Renal Epithelial Cells
}

\author{
Kenichiro Kitamura and R. Tyler Miller \\ Nephrology Division and Department of Internal Medicine, University of Texas Southwestern Medical Center, Dallas, Texas 75235-8856
}

\begin{abstract}
To study signaling pathways regulated by $\alpha_{8}$ and $\alpha_{11}$ in renal epithelial cells, we expressed mutant, activated forms of $\alpha_{\text {s }}$ and $\alpha_{11}$ in a continuous proximal tubule cell line (MCT cells). $\alpha_{\mathrm{sQ227L}}$ increased cAMP production, and $\alpha_{110204 \mathrm{~L}}$ reduced forskolin-sensitive cAMP production. $\alpha_{\text {110204L }}$ increased and $\alpha_{\mathrm{sQ227} \mathrm{L}}$ decreased bradykinin-induced $\mathrm{Ca}$ influx across the cell membrane, but neither mutant affected bradykinin-stimulated intracellular Ca release or basal $\mathrm{Ca}$ influx. Bradykinin-stimulated Ca influx was reduced by dibutyryl cAMP, isoproterenol, and forskolin. Expression of a mutant regulatory type I subunit for cAMP-dependent protein kinase with reduced affinity for CAMP and treatment with KT-5720, a specific cAMP-dependent protein kinase inhibitor, enhanced $\mathrm{Ca}$ influx to a degree similar to that in cells expressing $\alpha_{\mathrm{ilQ} 204 \mathrm{~L}}$. Bradykinin-stimulated c-fos mRNA expression is partially dependent on extracellular Ca. $\alpha_{\mathrm{sQ227}}$ reduced and $\alpha_{\text {ile204L }}$ enhanced bradykinin-stimulated c-fos expression. Consequently, in bradykinin-stimulated cells, the adenylyl cyclase system regulates $\mathrm{Ca}$ influx through cAMP-dependent protein kinase, but not intracellular Ca release. Furthermore, the $\mathrm{Ca}$ influx mechanism acts as an integrator of two signaling pathways such that Ca-dependent signals are damped by activators of adenylyl cyclase and enhanced by inhibitors of adenylyl cyclase. (J. Clin. Invest. 1994. 94:328-336.) Key words: G protein • adenylyl cyclase • intracellular calcium • membrane signal transduction
\end{abstract}

\section{Introduction}

The heterotrimeric $G$ proteins are a family of proteins that couple receptors on the outside of cells to effector systems such as enzymes or ion channels that alter the intracellular environment (1-4). Effectors can be regulated by $G$ proteins at multiple levels including direct interaction and by second messengerdependent protein kinases. Despite considerable effort, the effector systems regulated by specific $G$ proteins have not been defined fully in most cases for a number of reasons. Many ligands for $G$ protein-coupled receptors such as catecholamines, acetylcholine, parathyroid hormone, and angiotensin II

Address correspondence to R. Tyler Miller, Internal Medicine/Nephrology, University of Texas Southwestern Medical Center, 5323 Harry Hines Boulevard, Dallas, TX 75235-8856.

Received for publication 16 April 1993 and in revised form 10 March 1994.

J. Clin. Invest.

(c) The American Society for Clinical Investigation, Inc. 0021-9738/94/07/0328/09 \$2.00

Volume 94, July 1994, 328-336 appear to activate multiple $G$ proteins, so that the contribution of individual members of the $G$ protein family to signaling pathways is difficult to determine. The individual components are difficult to study because they are expressed in a tissuespecific manner at low levels. Reconstitution studies demonstrate that an individual $G$ protein may be capable of participating in interactions with a variety of receptors and effectors, but the specific makeup of a signaling pathway depends on its cellular context. Consequently, signaling pathways in cells such as renal epithelial cells, fibroblasts, and excitable cells are likely to be different.

Most evidence indicates that $\alpha$ subunits carry the specificity for receptor and effector interactions, although roles for $\beta \gamma$ subunits in effector regulation are being defined (5-8). G proteins are classified according to their $\alpha$ chains and can be grouped into families according to their structures (9). $\alpha_{\mathrm{s}}$ regulates adenylyl cyclase in all tissues studied, and in cardiac myocytes appears to regulate $\mathrm{Ca}$ channels through second messenger-dependent protein kinases and possibly a direct membranedelimited system $(10,11)$. The mammalian $\mathrm{G}$ protein $\alpha_{\mathrm{i}}$ family includes $\alpha_{\mathrm{i} 1}-\alpha_{\mathrm{i} 3}, \alpha_{\mathrm{o}}, \alpha_{\mathrm{z}}$, and the transducins (9). These proteins are all products of distinct genes, yet are highly homologous. With the exception of the transducins that are expressed exclusively in the retina, knowledge of the function of individual members of this family is incomplete $(1-4,12) . \alpha_{i 1}-\alpha_{i 3}$ and $\alpha_{o}$ are pertussis toxin substrates and consequently are candidates for mediating processes that are guanine nucleotide-dependent and sensitive to inhibition by pertussis toxin. The processes potentially regulated by the pertussis toxin substrates include inhibition of hormone-stimulated adenylyl cyclases, stimulation of phospholipase $C$, regulation of phospholipase $A_{2}$, and $K, C a$, and $\mathrm{Na}$ channels $(1-4,10,11)$.

Intracellular $\mathrm{Ca}$ can be regulated by a variety of $\mathrm{G}$ proteindependent and -independent mechanisms including release from intracellular stores [usually in response to phospholipase $\mathrm{C}$ activation and inositol triphosphate $\left(\mathrm{IP}_{3}\right)^{1}$ production], $\mathrm{Ca}$ influx across the plasma membrane through a variety of $\mathrm{Ca}$ channels, and active transport out of the cytosol by Ca-ATPases (13-15). The $\mathrm{Ca}$ influx pathways in excitable tissues, neurons, and muscle cells are better defined structurally and pharmacologically than their counterparts in other tissues such as epithelial cells.

To study the effects of $\alpha_{i 1}$ and $\alpha_{\mathrm{s}}$ on regulation of the adenylyl cyclase ( $\mathrm{s}$ ) expressed in renal epithelial cells and intracellular $\mathrm{Ca}$, along with possible interactions of these systems, we expressed mutant, GTPase-deficient forms of $\alpha_{i 1}$ and $\alpha_{\mathrm{s}}$ in a renal epithelial cell line using a regulatable metallothionein promoter $(16,17)$. This system allowed us to study the effects

\footnotetext{
1. Abbreviations used in this paper: db-cAMP, dibutyryl cAMP; IBMX, 3-isobutyl-1-methyl zanthine; $\mathrm{IP}_{3}$, inositol triphosphate; Neo, neomycinresistant; PK, protein kinase.
} 
of each $\alpha$ chain individually and the effects of increased and decreased adenylyl cyclase activity. We chose this expression system in order to avoid high level expression of activated proteins. In these studies, we demonstrate that the mutant $\alpha_{\mathrm{s}}$ stimulates and the mutant $\alpha_{i 1}$ inhibits adenylyl cyclase. We identify a new bradykinin-sensitive $\mathrm{Ca}$ influx pathway in which activity is modulated by the adenylyl cyclase system through cAMP-dependent protein kinase (PK A). Ca influx is inversely related to adenylyl cyclase activity regulated by the expressed $\alpha$ chains such that $\mathrm{Ca}$-dependent signals are modulated by the adenylyl cyclase system in MCT cells. A Ca influx pathway that is inhibited by the adenylyl cyclase system has not been described previously.

\section{Methods}

Materials. Restriction and DNA-modifying enzymes were obtained from Promega Biotech (Madison, WI) and radionucleotides from DuPont-New England Nuclear (Boston, MA). Fura-2 was purchased from Molecular Probes (Eugene, OR) and KT-5720 from LC Laboratories (Woburn, MA). Tissue culture medium, serum, and synthetic peptides (Kemptide and PK A inhibitor) were purchased from Gibco Laboratories (Grand Island, NY). Tissue culture plasticware was from Falcon. Other chemicals were from Sigma Chemical Co. (St. Louis, MO) or molecular biology grade from Fisher Scientific Co. (Fair Lawn, NJ).

Cell culture. MCT cells (an SV40-transformed mouse proximal tubule cell line) were obtained from Eric Neilson, University of Pennsylvania Medical School (18). The cells were grown in a variety of plastic tissue culture plates and were maintained in RPMI 1640 with 5\% fetal calf serum (Gibco Laboratories). Medium for cell lines expressing mutant $\alpha$ chains or the vector alone also contained G-418 (Gibco Laboratories ), $250 \mu \mathrm{g} / \mathrm{ml}$. 24-h before experiments, cells were serum deprived, and G-418 was removed. Where indicated, $\mathrm{CdCl}_{2}(1 \mu \mathrm{M})$ was present in the medium for $8 \mathrm{~h}$. This protocol resulted in maximal induction of mRNA for the mutant $\alpha$ chains. All cells were grown in $5 \% \mathrm{CO}_{2}, 95 \%$ air incubators at $37^{\circ} \mathrm{C}$.

Mutagenesis. Rat cDNAs coding for $\alpha_{\mathrm{s}}$ (the 52-kD form) and $\alpha_{i 1}$ were obtained from Randall Reed, Johns Hopkins University Medical School (19). Point mutations changing Q227 to L in $\alpha_{\mathrm{s}}$ and Q204 to $\mathrm{L}$ in $\alpha_{\mathrm{i} 1}$ were made using the Bio-Rad Laboratories (Richmond, CA) Phagemid Mutagene kit (20). The cDNAs coding for the $\alpha$ chains were subcloned into PTz19u (Bio-Rad Laboratories) using HindIII sites for $\alpha_{\mathrm{s}}$ and EcoRI sites for $\alpha_{\mathrm{i} 1}$. Plasmids containing the $\alpha$ chains were transformed into Escherichia coli $\mathrm{CJ} 236$, and single-stranded DNA containing uracil in place of thymidine was produced by infection of the bacteria with helper phage. The mutagenic oligonucleotides, bp 852-

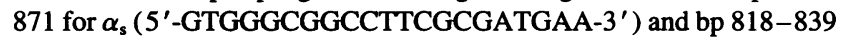
for $\alpha_{i 1}$ ( $5^{\prime}$-CGTGGGAGGCCTTAGATCAGAGCG-3'), were annealed to their respective single-stranded templates and were incubated with dNTPs $(0.4 \mathrm{mM})$, DNA polymerase, and T4 DNA ligase in buffer containing (mM) 23 Tris (pH 7.9), $5.0 \mathrm{MgCl}_{2}, 35 \mathrm{NaCl}, 1.5 \mathrm{DTT}$, and $0.75 \mathrm{ATP}$ for $5 \mathrm{~min}$ on ice, at $25^{\circ} \mathrm{C}$ for $5 \mathrm{~min}$, and at $37^{\circ} \mathrm{C}$ for $90 \mathrm{~min}$. The reaction mix was then transformed into $E$. coli MV-1190, and colonies were selected on ampicillin plates. Double-stranded sequencing was performed on DNA purified from individual colonies, to document the presence of mutations (20).

DNA constructions. The expression vector Zem-228, which contains a mouse metallothionein (MT-1) promoter, an SV40 poly A sequence, and the gene for G-418 resistance, was obtained from Stan McKnight, University of Washington Medical School (The construction or use of Zem-228 has not been published, but the MT-1 promoter used in it is the same as that described in reference 21). The mutagenized $\alpha$ chains, $\alpha_{\mathrm{sQ227L}}$ and $\alpha_{\mathrm{ilQ204L}}$, were subcloned into Zem-228 at the unique BamHI cloning site using blunt end ligation. Rev B (the mutant type I regulatory subunit for cAMP-dependent protein kinase) was obtained from Stan McKnight and used in the vector described in reference 21 .
Mammalian cell expression. $15 \mu \mathrm{g}$ of plasmid DNA [Zem-228 without insert, $\alpha_{\mathrm{sQ22 \pi}}, \alpha_{\mathrm{ilQ204L}}$, and Rev B (the mutant protein kinase A type I regulatory subunit in a similar vector)] was transfected into MCT cells using lipofectin reagent (Bethesda Research Laboratories, Bethesda, MD). The Rev B plasmid, which does not contain a neomycin-resistance gene, was co-transfected with $1.5 \mu \mathrm{g}$ of pSV2-Neo. The cells were grown for $48 \mathrm{~h}$, and neomycin-resistant clones were selected in $500 \mu \mathrm{g} / \mathrm{ml} \mathrm{G}-418$ (Gibco Laboratories) by limiting dilution. Expression of cDNAs was documented by RNA blots, immunoblots, and demonstration of the appropriate biochemical phenotype.

Immunoblots. Cell extracts were prepared by lysis of whole cell monolayers in $2 \%$ SDS. Protein content was normalized by Lowry protein assay (with SDS in the standards) (22), and $50 \mu \mathrm{g}$ of cell extract was size fractionated on 9\% SDS-polyacrylamide gels and electrotransferred to nitrocellulose. The blots were blocked in blotto (powdered nonfat milk, $5 \%$; $50 \mathrm{mM}$ Tris pH $7.4 ; 150 \mathrm{mM} \mathrm{NaCl} ; 5.0 \mathrm{mM}$ EDTA; $0.01 \% \mathrm{Na}$ Azide; and $0.05 \%$ Tween 20 ) and incubated in blotto with the primary antibodies. The antibody to $\alpha_{s}$ that recognizes the unique region of $\alpha_{\mathrm{s}}$ (amino acids 323-339) and was produced in the Bourne laboratory, was obtained from Henry Bourne (17). The $\alpha_{i}$ antibody P960 was obtained from Suzanne Mumby (23). The blots were washed five times in blotto and incubated with the secondary antibody, ${ }^{125}$ I-labeled goat anti-rabbit IgG Fab (New England Nuclear, Boston, MA), washed five times in blotto, air dried, and exposed to film.

RNA blots. Total RNA was prepared from cells grown in 100$\mathrm{mm}$ dishes by the guanidinium thiocyanate method followed by $\mathrm{CsCl}$ centrifugation. $10 \mu \mathrm{g}$ of total RNA was size fractionated on $0.8 \%$ formaldehyde-agarose gels, transferred to a nylon membrane (Gene Screen; New England Nuclear), and probed (20). Probes for the RNA blots were as follows: rat $\alpha_{\mathrm{s}}$, the 1,389-bp HindIII fragment that contains the entire coding region; for rat $\alpha_{i 1}$, the XbaI-EcoRI fragment that contains $600 \mathrm{bp}$ of the 3' UTR; for rat glyceraldehyde-3-phosphate dehydrogenase, 1,380-bp PstI-PstI fragment that contains the entire coding region (18); and for c-fos, the full length rat cDNA (a gift of Dr. T. Curran) $(19,24,25)$. The probes were labeled with $\left[{ }^{32} \mathrm{P}\right] \mathrm{dATP}$ by the random primer method (Primagene; Promega).

cAMP production measurements. CAMP production was measured as $\left[{ }^{3} \mathrm{H}\right]$ cAMP formation after incubation of cells overnight in serumfree medium with $2 \mu \mathrm{Ci} / \mathrm{ml}\left[{ }^{3} \mathrm{H}\right]$ adenine $(26,27)$. For measurement of intracellular cAMP, the cells were washed twice with PBS and incubated in $1.0 \mathrm{ml}$ of serum-free medium containing $2.0 \mathrm{mM} 3$-isobutyl1-methyl xanthine (IBMX) and hormones or activators as indicated. After $30 \mathrm{~min}$ in the incubator, the reaction was terminated by aspiration of the medium and addition of $1.0 \mathrm{ml}$ of $10 \%$ TCA. cAMP production was linear for $45 \mathrm{~min}$. The cells were held at $4^{\circ} \mathrm{C}$ for $30 \mathrm{~min}$, the medium was removed, and $\left[{ }^{3} \mathrm{H}\right]$ cAMP was isolated by column chromatography by the method of Salomon et al. (28). The stop solution (10\% TCA) contained $\sim 800 \mathrm{cpm} / \mathrm{ml}$ of $\left[{ }^{32} \mathrm{P}\right]$ cAMP to correct for variable recovery by individual columns. The precipitated protein was dissolved in $1.0 \mathrm{ml}$ of $1.0 \mathrm{M} \mathrm{NaOH}$ and assayed for protein by the method of Lowry et al. (23). Where indicated, pertussis toxin was added to cell culture medium at a concentration of $200 \mathrm{ng} / \mathrm{ml}$ for $8 \mathrm{~h}$ before the production assay. All points are the mean of triplicate samples and are expressed as $\mathrm{cpm}\left[{ }^{3} \mathrm{H}\right] \mathrm{cAMP} / \mathrm{min}$ per $\mathrm{mg}$ protein $\pm \mathrm{SEM}$.

Intracellular $\mathrm{Ca}$ measurements. Intracellular $\mathrm{Ca}$ was measured fluorometrically in Fura-2-loaded cells in suspension. Approximately 5 $\times 10^{7}$ cells were trypsinized with EDTA, washed twice with uptake medium [(mM) $140 \mathrm{NaCl} ; 5.0 \mathrm{KCl} ; 1.0 \mathrm{MgCl}_{2} ; 10$ HEPES, pH 7.4; $1.0 \mathrm{mg} / \mathrm{ml} \mathrm{BSA}$ and $2.0 \mathrm{mg} / \mathrm{ml}$ glucose ] and resuspended and incubated in $2.0 \mathrm{ml}$ of uptake medium containing $2.5 \mu \mathrm{M}$ Fura-2-AM for $30 \mathrm{~min}$ at $35^{\circ} \mathrm{C}$. The cells were washed again and resuspended in $2.0 \mathrm{ml}$ of uptake medium. $50 \mu \mathrm{l}$, or $\sim 10^{6}$ cells, was diluted into $2.0 \mathrm{ml}$ of uptake medium at $37^{\circ} \mathrm{C}$ with constant stirring for studies (29).

Ca measurements were made in a LS-5B spectrometer or an SLM $8000 \mathrm{C}$ fluorimeter (Perkin-Elmer Cetus Instruments, Norwalk, CT) (29). Excitation was at $340 \mathrm{~nm}$ and emission at $500 \mathrm{~nm}$. At the end of studies, $\mathrm{Ca}$ measurements were calibrated by lysing the cells with digito$\operatorname{nin}(50 \mu \mathrm{g} / \mathrm{ml})$ and $2.0 \mathrm{mM}$ Ca to obtain maximum fluorescence $\left(F_{\max }\right)$ 
and then adding $10 \mathrm{mM}$ EDTA (above $\mathrm{pH} \mathrm{8.15)} \mathrm{to} \mathrm{obtain} \mathrm{minimum}$ fluorescence $\left(\mathrm{F}_{\min }\right)$. Intracellular $\mathrm{Ca}$ was calculated according to the method of Tsien (30).

PKA activity assay. PKA activity was measured as described by Clegg et al. (21) using Kemptide (LRRASLG) as a synthetic substrate (21). Cells were washed in PBS, scraped in isotonic buffer [ $(\mathrm{mM}) 30$ Hepes, $\mathrm{pH}$ 7.4; 250 sucrose; 0.1 PMSF; 1 pepstatin A]. The cells were centrifuged, resuspended in homogenization buffer $\left[(\mathrm{mM}) 10 \mathrm{Na} \mathrm{PO}_{4}\right.$, pH 7.0; 1 EDTA; 1 DTT; 250 sucrose; 0.1 PMSF; 1 pepstatin A; and 0.5 IBMX], and disrupted by sonication. The particulate fraction was removed by centrifugation and the supernatant saved and assayed for protein content. Approximately $10 \mu \mathrm{g}$ of protein was used for each assay. To measure specific kinase activity, the activity of samples incubated with PKI (TYADFIASGRTGRRN, a specific peptide inhibitor of PKA) in addition to Kemptide was subtracted from the activity of samples incubated with Kemptide alone. Cell extracts were assayed under basal conditions and in the presence of cAMP $\left(10^{-5} \mathrm{M}\right)$ in duplicate for $5 \mathrm{~min}$ during which time the assay was linear. The assay buffer contained $200 \mu \mathrm{M}$ ATP, $10 \mathrm{mM} \mathrm{Mg}$ acetate, $30 \mu \mathrm{M}$ Kemptide, $20 \mathrm{mM}$ Tris, $0.5 \mathrm{mM}$ IBMX, $10 \mathrm{mM}$ DTT, and $0.00225 \mathrm{mCi}\left[\gamma-{ }^{32} \mathrm{P}\right] \mathrm{ATP}$ per tube in a final volume of $50 \mu \mathrm{l}$. Reactions were stopped by spotting 25 $\mu \mathrm{l}$ from each tube on phosphocellulose and rapid washing of them in $75 \mathrm{mM}$ phosphoric acid. Samples were assayed in duplicate and repeated three times with similar results.

Statistical analysis. Experimental groups were compared by ANOVA using the InStat biostatics program from GraphPad Software (San Diego, CA). Multiple comparisons among groups were made using the Student-Newman-Keuls test. $P$ values $<0.05$ were considered significant.

\section{Results}

Selection of clones expressing mutant $\alpha$ chains. Clonal G-418resistant cell lines transfected with $\alpha_{\mathrm{sQ227L}}, \alpha_{\mathrm{ilQ204L}}$, and the vector without insert (Zem-228) were obtained by limiting dilution. Cell lines were screened for expression of $\alpha_{\mathrm{sQ227L}}$ by RIA for cAMP and chosen on the basis of increased basal and a Cddependent increase in CAMP production. Eight potential clones expressing $\alpha_{\mathrm{sQ227L}}$ were screened, seven of which were positive. Clones transfected with $\alpha_{\mathrm{iQ} 204 \mathrm{~L}}$ were screened for expression of the cDNA by RNA blot (see below). Six potential clones expressing $\alpha_{\mathrm{ilQ} 204 \mathrm{~L}}$ were screened. Five of these clones were positive for $\alpha_{\mathrm{ilQ204L}} \mathrm{mRNA}$ and inhibition of forskolin-stimulated cAMP production. The cell line with the best regulation of adenylyl cyclase activity by $\mathrm{Cd}$ in each group was selected for further study.

Expression of mutant $\alpha$ chain cDNAs and protein. Successful expression of the cDNAs in MCT cells was shown by RNA blot in which unique mRNAs of $1.55 \mathrm{~kb}$ (corresponding to $\alpha_{\mathrm{sQ227L}}$ ) and $2.15 \mathrm{~kb}$ (corresponding to $\alpha_{\mathrm{ilQ204 \textrm {L }}}$ ) were present and regulated by $\mathrm{Cd}$ (data not shown). Immunoblots of extracts from cells expressing the mutant $\alpha$ chains using antisera for $\alpha_{\text {s }}$ or the $\alpha_{\mathrm{i}} \mathrm{s}$ demonstrate increased antigen in the respective cell lines compared to wild-type or neomycin-resistant (neo) control cells (Fig. $1 A$ and $B$ ). The first lane of both immunoblots contains cholate extracts of rat brain ( $60 \mu \mathrm{g}$ of protein) as $\mathrm{G}$ protein $\alpha$ chain standards. Proteins in these lanes migrate slightly faster than the lanes containing MCT cell extracts because they contain cholate rather than SDS. Fig. $1 A$ shows an immunoblot of extracts of wild-type, neomycin-resistant control cells and cells expressing $\alpha_{\mathrm{sQ227L}}$ with an antibody to $\alpha_{\mathrm{s}}$ (17). In all cell lines without and with $\mathrm{Cd}$, bands at 45 and $52 \mathrm{kD}$ are seen that correspond to the splice variants of $\alpha_{s}$. In the cells expressing $\alpha_{\mathrm{sQ227L}}$, in the presence of Cd a large increase in
A

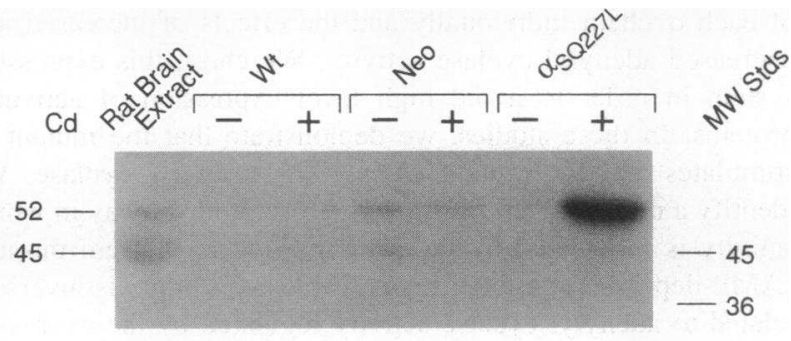

B

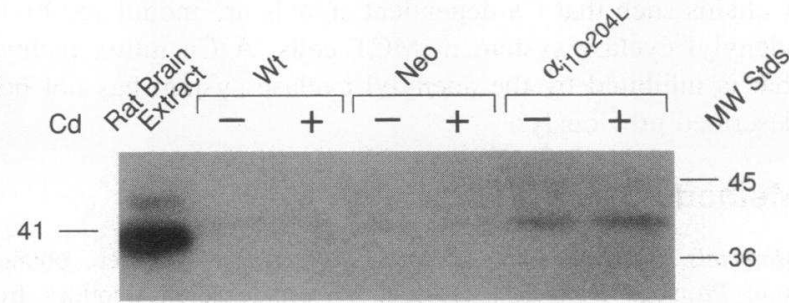

Figure 1. Immunoblots of MCT cell extracts using antibodies to $\alpha_{\mathrm{s}}$ and $\alpha_{\mathrm{i}}$. The cells were treated without and with $\mathrm{CdCl}_{2}$ as described in Methods. $50 \mu \mathrm{g}$ of extract protein were loaded in each lane except for lane 1 labeled Rat brain extract, which contains $60 \mu \mathrm{g}$ of cholate extract. (A) Wild-type (WT), neomycin-resistant control cells (Neo) and cells expressing $\alpha_{\mathrm{sQ227L}}$ blotted with an antibody to $\alpha_{\mathrm{s}}$. (B) A similar immunoblot but with cells expressing $\alpha_{\mathrm{ilQ} 204 \mathrm{~L}}$ blotted with antibody P960 that recognizes $\alpha_{\mathrm{i}}$ s.

antigen at $52 \mathrm{kD}$ is seen that corresponds to the mutant protein and correlates with mRNA levels. Fig. $1 B$ shows an immunoblot of wild-type and neomycin-resistant cells and cells expressing $\alpha_{\mathrm{ilQ204L}}$ without and with $\mathrm{Cd}$ pretreatment. In this case, the antibody used was p960 which recognizes the $\alpha_{i} \mathrm{~s}, \alpha_{\mathrm{o}}, \alpha_{\mathrm{z}}$, and other $\alpha$ chains (23). In the cells expressing $\alpha_{\mathrm{ilQ204L}}$, an increase in antigen at $41 \mathrm{kD}$ is seen that corresponds to the expressed protein. As is the case for the RNA blot, the basal level of expression of the mutant $\alpha_{i 1}$ is higher and increases less with Cd pretreatment than the mutant $\alpha_{\mathrm{s}}$.

Adenylyl cyclase phenotypes. The mutations in both $\alpha$ chains reduce their GTPase activity and cause persistent activation by maintaining them in the GTP-bound conformation (16, $17,27,31,32)$. Under normal conditions in the cell, both $\alpha_{\text {s }}$ and $\alpha_{i 1}$ have significant rates of spontaneous guanine nucleotide exchange, but remain inactive in the presence of GTP because the rate of GTP hydrolysis is more rapid than their nucleotide exchange rates $(2,33,34)$. However, the two mutant $\alpha$ chains ( $\alpha_{\mathrm{sQ227L}}$ and $\alpha_{\mathrm{ilQ204 \textrm {L }}}$ ) are in their active forms in the presence of normal intracellular GTP concentrations because of their very slow rate of GTP hydrolysis. The ability of hormones to regulate cAMP production is altered by expression of $\alpha_{\mathrm{ilQ204L}}$ (Fig. 2). Cd pretreatment of cells was not used in these studies because even in the absence of $\mathrm{Cd}$, the cAMP production is maximally inhibited by $\alpha_{\mathrm{ilQ} 204 \mathrm{~L}}$ and is measurably increased by $\alpha_{\mathrm{sQ227L}}$ (Fig. 2).

In control $(\mathrm{NeO})$ cells, bradykinin $\left(10^{-8} \mathrm{M}\right)$ inhibits forskolin-stimulated cAMP production by $\sim 50 \%$, an effect that is blocked by pertussis toxin. Pertussis toxin alone has no effect on forskolin-stimulated cAMP production. Similar results were obtained with wild-type cells. The cells expressing $\alpha_{\mathrm{sQ227}}$ have higher basal and forskolin-stimulated levels of cAMP production than controls. Bradykinin inhibits forskolin-stimulated cAMP production in these cells by $\sim 20 \%$. cAMP production 


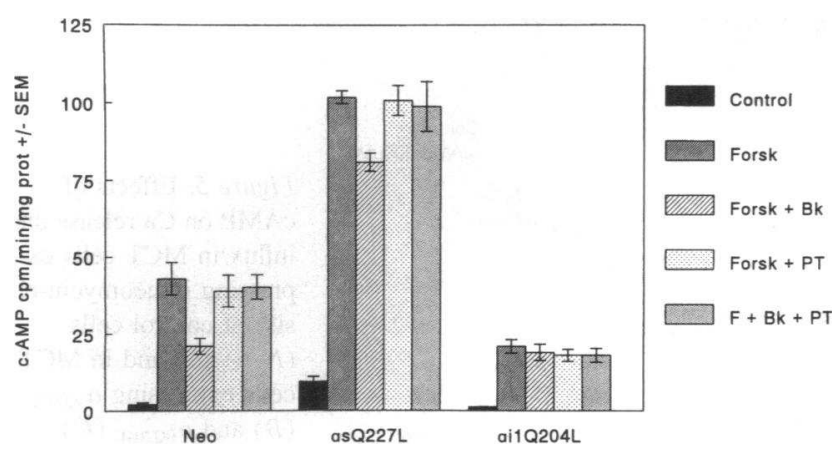

Figure 2. Effect of expression of mutant $\alpha$ chains on hormonal responses in neomycin-resistant MCT cells ( $\mathrm{Neo}$ ), MCT cells expressing $\alpha_{\mathrm{sQ227 \textrm {L }}}$, and MCT cells expressing $\alpha_{\mathrm{ilQ} 204 \mathrm{~L}}$. The cells were serum deprived and preincubated with $\left[{ }^{3} \mathrm{H}\right]$ adenine overnight. Intracellular cAMP accumulation was measured by separation of $\left[{ }^{3} \mathrm{H}\right]$ cAMP from other compounds by column chromatography. Column recoveries were corrected by inclusion of tracer $\left.{ }^{32} \mathrm{P}\right] \mathrm{cAMP}$ in each sample. Forskolin $(100 \mathrm{nM})$ and bradykinin $\left(10^{-8} \mathrm{M}\right)$ were added as indicated. Pertussis toxin was present as indicated at $200 \mathrm{ng} / \mathrm{ml}$ for $8 \mathrm{~h}$ before cAMP production assays. cAMP accumulation is expressed as $\mathrm{cpm} / \mathrm{min}$ per $\mathrm{mg}$ protein $\pm \mathrm{SEM}$. Each point is the mean of triplicate samples, and experiments were repeated three times.

by forskolin-treated cells expressing $\alpha_{\mathrm{ilQ} 204 \mathrm{~L}}$ is approximately the same level as control cells treated with forskolin and bradykinin. In cells expressing $\alpha_{\mathrm{ilQ} 204 \mathrm{~L}}$, forskolin increases cAMP production, but less than in control cells, similar to the level found in control cells in the presence of forskolin and bradykinin. Treatment with forskolin and bradykinin, forskolin and pertussis toxin, or forskolin, pertussis toxin, and bradykinin does not significantly alter cAMP production from the forskolinstimulated level. At the level at which it is expressed in this clonal cell line, $\alpha_{\mathrm{ilQ} 204 \mathrm{~L}}$ appears to maximally inhibit forskolinstimulated cAMP accumulation, and bradykinin has no additive effect.

Regulation of intracellular $\mathrm{Ca}$ in MCT cells expressing mutant $\alpha$ chains. Bradykinin was used as a potent activator of the phospholipase $\mathrm{C}$-intracellular $\mathrm{Ca}$ system (35). A bradykinin dose that produced a maximal effect $\left(10^{-8} \mathrm{M}\right)$ was chosen based on preliminary dose-response studies. Cells were studied in the absence of $\mathrm{CdCl}_{2}$ because the effects of both mutant $\alpha$ chains were present under these conditions, and possible complicating effects of $\mathrm{Cd}$ were avoided. Hormone-dependent $\mathrm{Ca}$ release from intracellular stores in response to bradykinin was studied in a $0 \mathrm{Ca}$ medium to prevent $\mathrm{Ca}$ influx across the cell membrane. $\mathrm{Ca}$ influx was then measured by adding $\mathrm{Ca}$ (2.0 $\mathrm{mM}$ ) to the medium. Mn-induced quench of intracellular Fura2 fluorescence was used as a confirmatory measure of plasma membrane Ca permeability because it enters cells by the same pathway as $\mathrm{Ca}$ and reflects uptake by $\mathrm{IP}_{3}$-sensitive stores (15). Expression of the mutant $\alpha$ chains had no significant effect on basal intracellular $\mathrm{Ca}$ or bradykinin-induced $\mathrm{Ca}$ release from intracellular stores (Fig. $3 \mathrm{~A}$ ). The basal and peak values (mean \pm SEM) for at least six separate tracings are respectively (Ca nM): $122 \pm 11$ and $706 \pm 70 \mathrm{Neo}, 99 \pm 13$ and $619 \pm 51$ $\alpha_{\mathrm{sQ} 227 \mathrm{~L}}$, and 106 \pm 9 and 713 $\pm 66 \alpha_{\mathrm{ilQ204L}}$. The differences among the peak and basal intracellular $\mathrm{Ca}$ values for the three groups were not significantly different $(P>0.05$, ANOVA). However, expression of these $\alpha$ chains markedly altered Ca influx across the cell membrane in the presence of bradykinin as measured

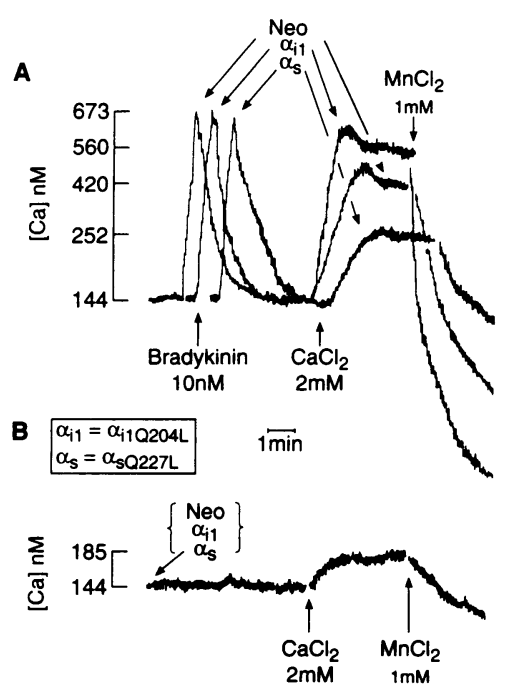

Figure 3. Bradykinin-dependent $\mathrm{Ca}$ release from intracellular stores and $\mathrm{Ca}$ influx in MCT cells expressing mutant $\alpha$ chains. MCT cells, which had been serum deprived were trypsinized, loaded with Fura-2, and studied in a fluorimeter with constant stirring. In $A$, release of $\mathrm{Ca}$ from intracellular stores in response to bradykinin is compared in control cells $(\mathrm{NeO})$ and cells expressing $\alpha_{\mathrm{sQ227L}}$ and $\alpha_{\mathrm{iQ} 204 \mathrm{~L}}$. Bradykinin $\left(10^{-8} \mathrm{M}\right)$ was added in Ca-free medium. When intracellular $\mathrm{Ca}$ returned to baseline,

$\mathrm{CaCl}_{2}$ was added to the medium to bring the concentration to $2.0 \mathrm{mM}$. When intracellular $\mathrm{Ca}$ reached a plateau, $\mathrm{MnCl}_{2}$ was added to a final concentration of $1.0 \mathrm{mM}$. In $B$, the experiment was repeated except that bradykinin was not present. The Ca signal could not be calibrated in these individual experiments due to the presence of Mn. However, in similar experiments using aliquots of cells from the same batches and each cell line, release of $\mathrm{Ca}$ from intracellular stores was similar in all cell lines and to that shown in $A$.

by the intracellular Ca plateau and rate of quench of Fura- 2 by Mn. Fig. $3 A$ shows Ca tracings representative of at least six experiments from control neomycin-resistant MCT cells (Neo) and cells expressing $\alpha_{\mathrm{sQ227L}}$ and $\alpha_{\mathrm{ilQ204L}}$. When $2.0 \mathrm{mM} \mathrm{Ca}$ is added to the extracellular medium and enters the cells, fluorescence rises in all three cell lines. $\mathrm{Ca}$ influx is most rapid (as reflected by the slope of the line) and reaches a higher plateau in cells expressing $\alpha_{\mathrm{ilQ} 204 \mathrm{~L}}$ and is slowest in cells expressing $\alpha_{\mathrm{sQ227L}}$. A comparison of the intracellular Ca plateau values is provided in Table I along with those for studies with isoproterenol and forskolin (Fig. 4). The rate of $\mathrm{Ca}$ influx as reflected by the slope of the tracing after Mn addition is $0.44 \pm 0.07$ that of control for the $\alpha_{\mathrm{sQ227L}}$-expressing cells, a significant reduction ( $P<0.001$ ), and $1.52 \pm .036$ for the $\alpha_{\mathrm{ilQ204L}}$-expressing compared to Neo, a significant increase $(P<0.001)$.

As expected on the basis of the $\mathrm{Ca}$ studies, expression of the $\alpha$ chains had no effect on $\mathrm{IP}_{3}$ production [measured with a cerebellar $\mathrm{IP}_{3}$ binding protein assay (29)]. In Neo cells and cells expressing $\alpha_{\mathrm{sQ} 227 \mathrm{~L}}$ and $\alpha_{\mathrm{ilQ} 204 \mathrm{~L}}, \mathrm{IP}_{3}$ production (mean $\pm \mathrm{SD}$ ) in the basal state was $2.62 \pm 0.287 \times 10^{-9}, 2.03 \pm 1.46 \times 10^{-9}$, and $2.99 \pm 2.32 \times 10^{-9}$ and rose to a maximum of $3.05 \pm 1.35$ $\times 10^{-8}, 2.9 \pm 1.38 \times 10^{-8}$, and $3.12 \pm 1.12 \times 10^{-8}$ at $20 \mathrm{~s}$ in the respective cell lines after stimulation with bradykinin. These differences among the basal and peak values are not statistically significant (ANOVA, $P>0.05$ ). However, the differences between the peak and basal values were statistically significant $(P<0.01$, ANOVA $)$.

$\mathrm{Ca}$ influx is altered by the presence of mutant $\alpha$ chains only in the presence of bradykinin. Fig. $3 B$ shows typical tracings from experiments similar to those shown in Fig. $3 A$, but without stimulation by bradykinin. In these studies the rate of $\mathrm{Ca}$ influx and plateau is similar in all cell lines and substantially less than that in cells treated with bradykinin. 
Table I. Comparison of the Plateau Levels of Intracellular Ca in Neomycin-Resistant Control Cells (Neo), and MCT Cells

Expressing $\alpha_{s Q 227 L}$, and $\alpha_{i l Q 204 L}$ without and with Isoproterenol $\left(10^{-8} \mathrm{M}\right)$ or Forskolin $2.5 \times 10^{-5} \mathrm{M}$

\begin{tabular}{lccc}
\hline & Control & Isoproterenol & Forskolin \\
\hline Neo & $0.445 \pm 0.017$ & $\begin{array}{c}0.333 \pm 0.023^{*} \\
P<0.05\end{array}$ & $\begin{array}{c}0.26 \pm 0.021^{*} \\
P<0.001\end{array}$ \\
\hline$\alpha_{\text {SQ227L }}$ & $\begin{array}{c}0.104 \pm 0.008^{\ddagger} \\
P<0.05\end{array}$ & $\begin{array}{c}0.077 \pm 0.015 \\
P>0.05\end{array}$ & $\begin{array}{c}0.083 \pm 0.088 \\
P>0.05\end{array}$ \\
\hline$\alpha_{\text {ilQ204L }}$ & $0.63 \pm 0.04^{\ddagger}$ & $\begin{array}{c}0.353 \pm 0.12^{*} \\
P<0.001\end{array}$ & $\begin{array}{c}0.30 \pm 0.022^{*} \\
P<0.001\end{array}$ \\
\hline
\end{tabular}

These studies were performed as described for Figs. 3 and 4. To simplify comparisons, the plateau levels of intracellular $\mathrm{Ca}$ are expressed as the fraction of the peak intracellular $\mathrm{Ca}$ above the baseline intracellular $\mathrm{Ca}$ (mean \pm SEM). * Values that are statistically different from untreated cells expressing the same $\alpha$ chain. ${ }^{\ddagger}$ Values in untreated cells expressing the mutant $\alpha$ chains that statistically different from the Neo control cells by ANOVA.

While the changes in $\mathrm{Ca}$ influx could be explained by a direct effect of the $\alpha$ chains on the $\mathrm{Ca}$ influx pathway, they could also be due to regulation of $\mathrm{Ca}$ influx by the adenylyl cyclase system. To address this issue, we repeated the studies shown in Fig. $3 A$ in the presence of two activators of the adenylyl cyclase system: isoproterenol, which requires $\beta$ receptor- $\alpha_{\mathrm{s}}$-adenylyl cyclase coupling, and forskolin, which acts directly on adenylyl cyclase. Control (Neo) cells and cells expressing $\alpha_{\mathrm{sQ227L}}$ and $\alpha_{\mathrm{ilQ204L}}$ were pretreated with isoproterenol or forskolin in thi presence of IBMX 4 min before the addition of bradykinin (Fig. $4 A, B$, and $C$, respectively). These additions caused no change in basal intracellular $\mathrm{Ca}$ or bradykinin-induced $\mathrm{Ca}$ release from intracellular stores. However, isoprotere-

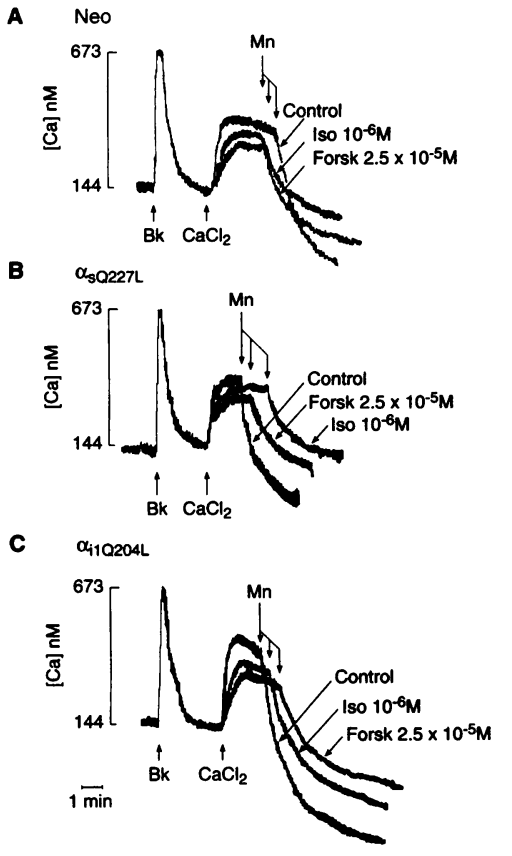

Figure 4. Effects of isoproterenol and forskolin on $\mathrm{Ca}$ release and influx in neomycin-resistant control cells $(\mathrm{Neo})(A)$ and in MCT cells expressing $\alpha_{\mathrm{sQ} 227 \mathrm{~L}}(B)$ and $\alpha_{\text {ilQ204L }}(C)$. The cells were serum deprived, trypsinized, loaded with Fura-2, and washed as above. They were then incubated in IBMX $(0.2$ $\mathrm{mM}$ ) and isoproterenol $\left(10^{-6} \mathrm{M}\right)$ or in forskolin $\left(2.5 \times 10^{-5} \mathrm{M}\right)$ for 4 min before bradykinin $\left(10^{-8} \mathrm{M}\right)$ was added. The remainder of the experiment was carried out as described in Fig. 3.

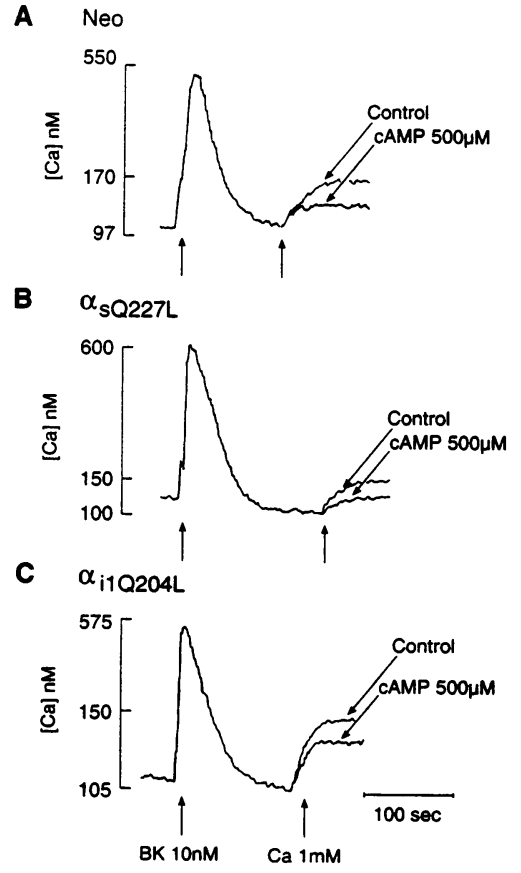

Figure 5. Effects of cAMP on Ca release and influx in MCT cells expressing in neomycin-resistant control cells $(\mathrm{Neo})(A)$ and in MCT cells expressing $\alpha_{\mathrm{sQ227L}}$ $(B)$ and $\alpha_{\mathrm{ilQ204L}}(C)$. Cells were treated with db-cAMP $15 \min \left(10^{-5}\right.$ M) before the addition of bradykinin, and $\mathrm{Ca}$ was added to a final concentration of $1.0 \mathrm{mM}$. Otherwise, studies were performed as described in Fig. 3 . The tracings were calibrated individually as described in Methods and are typical of at least three experiments.

nol and forskolin reduced $\mathrm{Ca}$ influx after bradykinin stimulation. The difference was statistically significant for the Neo and $\alpha_{\mathrm{il}-}$ Q204L-expressing cells. The reduction in $\mathrm{Ca}$ influx was not significant for the cells expressing $\boldsymbol{\alpha}_{\mathrm{sQ227L}}$, although in paired tracings, differences were evident. Similarly, although paired $\mathrm{Ca}$ tracings with isoproterenol and forskolin suggest that forskolin reduces $\mathrm{Ca}$ influx to a greater extent than isoproterenol, the differences are not statistically significant. A quantitative comparison of the intracellular Ca plateau level in the three cell lines under control conditions and in the presence of isoproterenol or forskolin is presented in Table I. As in Fig. $3 A$, the rate of quench of Fura-2 fluorescence by $\mathrm{Mn}$ corresponds to $\mathrm{Ca}$ influx and shows decreased rates of quench with forskolin or isoproterenol. These studies suggest that the effects of the expressed $\alpha$ chains on $\mathrm{Ca}$ influx are mediated by regulation of the adenylyl cyclase system.

Effects of cAMP on intracellular Ca in MCT cells. To demonstrate that cAMP is required for reduction of $\mathrm{Ca}$ influx in MCT cells, MCT cells were preincubated with dibutyryl cAMP (db-cAMP) $\left(10^{-4} \mathrm{M}\right)$ for $15 \mathrm{~min}$ before the addition of bradykinin. As shown in Fig. 5 and Table II, cAMP treatment reduced $\mathrm{Ca}$ influx in response to the addition of $1 \mathrm{mM}$ extracellular $\mathrm{Ca}$ in all three cell lines. The difference was statistically significant for the Neo and $\alpha_{\mathrm{ilQ204L}}$-expressing cells, but not for the cells expressing $\alpha_{\mathrm{sQ227L}}$. Similar results were obtained with chlorophenyl cAMP. These results demonstrate that direct elevation of cell cAMP without activation of receptors, G proteins or adenylyl cyclase is sufficient to alter $\mathrm{Ca}$ influx in MCT cells. The fact that $\mathrm{Ca}$ influx is not minimal and equal in all cell lines may be due to the relatively low cell permeability of hydrolysisresistant cAMP analogues.

The role of $c A M P$-dependent protein kinase in regulation of intracellular $\mathrm{Ca}$ in $\mathrm{MCT}$ cells. cAMP could regulate $\mathrm{Ca}$ influx in MCT cells by direct action such as through a cAMP-gated channel or through PKA. To distinguish between these two possibilities, we treated cells with a chemical inhibitor of 
Table II. Comparison of the Plateau Levels of Intracellular Ca in Neomycin-Resistant Control Cells (Neo), and MCT Cells Expressing $\alpha_{s Q 227 L}, \alpha_{i l Q 204 L}$ and Rev B

\begin{tabular}{lccc}
\hline & Control & cAMP & KT-5720 \\
\hline Neo & $0.16 \pm 0.095$ & $\begin{array}{c}0.088 \pm 0.018^{*} \\
P<0.05\end{array}$ & $\begin{array}{r}0.19 \pm 0.012 \\
P>0.05\end{array}$ \\
\hline$\alpha_{\mathrm{SQ} 227 \mathrm{~L}}$ & $\begin{array}{c}0.104 \pm 0.008^{\ddagger} \\
P<0.005\end{array}$ & $\begin{array}{c}0.077 \pm 0.015 \\
P>0.05\end{array}$ & $\begin{array}{c}0.28 \pm 0.038^{*} \\
P<0.01\end{array}$ \\
\hline$\alpha_{\mathrm{ilQ204 \textrm {L }}}$ & $\begin{array}{c}0.248 \pm 0.026^{\ddagger} \\
P<0.005\end{array}$ & $\begin{array}{c}0.15 \pm 0.011^{*} \\
P<0.05\end{array}$ & $\begin{array}{c}0.20 \pm 0.014 \\
P>0.05\end{array}$ \\
\hline Rev & $\begin{array}{c}0.030 \pm 0.055^{\ddagger} \\
P<0.01\end{array}$ & $\mathrm{ND}$ & $\mathrm{ND}$
\end{tabular}

These studies were performed as described in Figs. 5, 6, and 7. To simplify comparisons, the plateau levels of intracellular $\mathrm{Ca}$ are expressed as the fraction of the peak intracellular $\mathrm{Ca}$ above the baseline intracellular $\mathrm{Ca}$ (mean $\pm \mathrm{SEM})$. * Values that are statistically different from untreated cells expressing the same $\alpha$ chain. ND, not done. ${ }^{\ddagger}$ Values in untreated cells expressing the mutant $\alpha$ chains that are statistically different from the Neo control cells by ANOVA.

cAMP-dependent protein kinase, KT-5720 ( $1 \mu \mathrm{M}$ in DMSO for 5 min before $\mathrm{Ca}$ studies) and expressed a mutant type I regulatory subunit for PKA that results in cells that are deficient in PKA activity $(21,36)$. Fig. 6 and Table II show the effects of treatment of the three cell lines with KT-5720. The bradykinininduced $\mathrm{Ca}$ influx is increased in the cells expressing $\alpha_{\mathrm{sQ} 227 \mathrm{~L}}$, but not statistically different from untreated control cells expressing $\alpha_{\text {ilQ204L. }}$. These results indicate that cAMP acts through cAMPdependent protein kinase to reduce $\mathrm{Ca}$ influx in MCT cells. In cells expressing $\alpha_{\mathrm{ilQ} 204 \mathrm{~L}}$, okadaic acid $\left(10^{-7} \mathrm{M}\right)$ reduced $\mathrm{Ca}$ influx to approximately the level seen in untreated Neo cells, but the effects in control ( $\mathrm{Neo}$ ) cells and cells expressing $\alpha_{\mathrm{sQ227L}}$

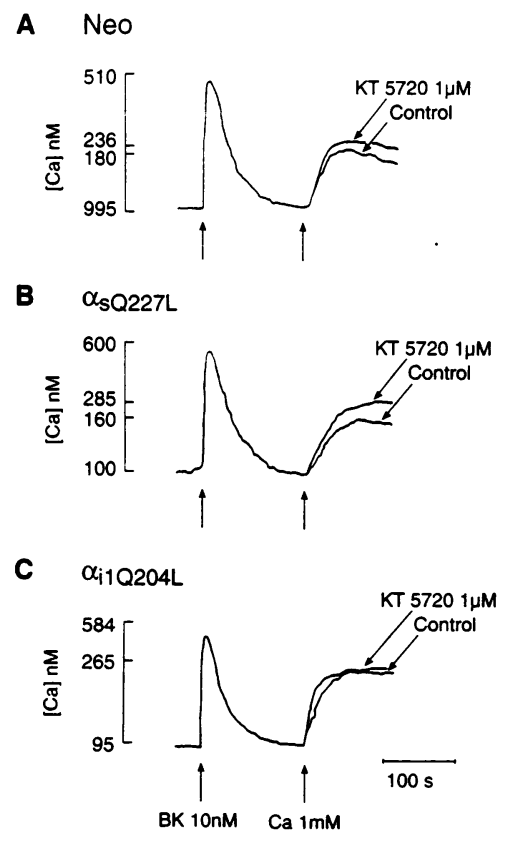

Figure 6. Effects of a chemical inhibitor of cAMP-dependent protein kinase (KT-5720) on Ca release and influx in neomycin-resistant control cells $(\mathrm{Neo})(A)$ and in MCT cells expressing $\alpha_{\mathrm{SQ} 227 \mathrm{~L}}(B)$ and $\alpha_{\mathrm{ir} 204 \mathrm{~L}}$ (C). The cells were treated with KT-5720 $10^{-6} \mathrm{M} 5 \mathrm{~min}$ before the addition of bradykinin and the final concentration of extracellular $\mathrm{Ca}$ was $1.0 \mathrm{mM}$. Otherwise, the studies were performed as described in Figure 3. The tracings were calibrated individually.

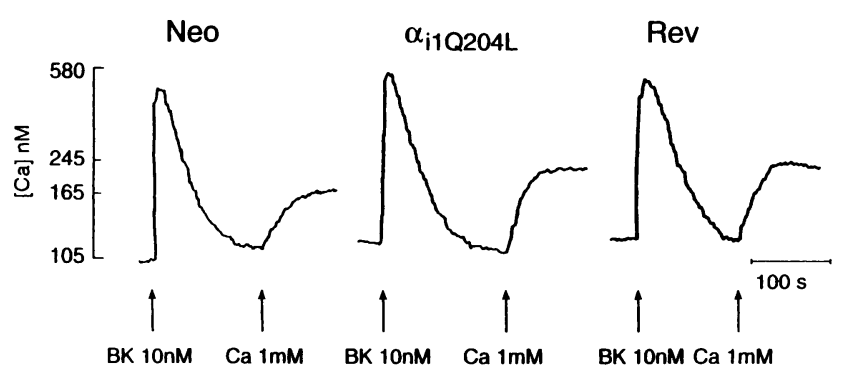

Figure 7. Comparison of the bradykinin-induced Ca signals in neomycin-resistant control cells, cells expressing $\alpha_{\mathrm{ilQ} 204 \mathrm{~L}}$, and Rev B, a cAMPresistant PKA regulatory subunit. The studies were performed as described in Fig. 3 except that the final extracellular $\mathrm{Ca}$ concentration was $1.0 \mathrm{mM}$. The tracings were calibrated individually, and are typical of at least five tracings.

were inconsistent. DMSO alone (up to $1 \%$ ) had no effect on $\mathrm{Ca}$ release or influx in these cells.

To confirm the results obtained with KT-5720 with an independent technique, we created clonal cell lines expressing Rev $B$, a mutant PKA regulatory subunit with reduced affinity for cAMP. Expression of this kinase reduces basal and cAMPstimulated levels of PKA activity in cells (21). Clonal cell lines expressing Rev B (provided by Stan McKnight, University of Washington) were selected as described above in Methods. The cell line with the highest basal level of Rev B expression based on RNA blots was selected for study because the $\mathrm{Ca}$ studies described above were done under basal conditions (in the absence of $\mathrm{Cd}$ ). Expression of Rev B was further documented by measuring PKA activity in cell extracts. Basal levels of PKA activity (measured as the ability of cell extracts to phosphorylate kemptide, a synthetic peptide substrate for PKA) in cells expressing Rev B and $\alpha_{\mathrm{ilQ204L}}$ are reduced compared to control (Neo) cells. The cAMP-stimulated level of kinase activity is reduced only in cells expressing $\operatorname{Rev} B$, whereas basal and forskolin-stimulated cAMP production are similar in control (Neo) cells and cells expressing Rev B. Basal and stimulated (cAMP $10^{-5} \mathrm{M}$ ) PKA activities ( $\mathrm{pmol} \mathrm{PO}_{4}$ transferred $/ \mathrm{min}$ per $\mu \mathrm{g}$ cell extract protein) are as follows: 7.2 and $15.7 \mathrm{Neo}, 4.6$ and $14.7 \alpha_{\mathrm{ilQ204L}}$, and 3.6 and 7.6 Rev B.

Fig. 7 and Table II show a comparison of bradykinin-induced changes in intracellular $\mathrm{Ca}$ in control cells, cells expressing $\alpha_{\mathrm{ilQ204L}}$, and cells expressing Rev B. The cells expressing $\alpha_{\mathrm{ilQ204L}}$ and Rev B are deficient in propagating cAMP-dependent signals. In all three cell types, $\mathrm{Ca}$ release from intracellular stores is similar. However, $\mathrm{Ca}$ influx across the cell membrane is similar in the cells expressing $\alpha_{\mathrm{ilQ} 204 \mathrm{~L}}$ and Rev B (ANOVA, $P>0.05$ ), but increased compared with controls (ANOVA, $P$ $<0.01)$. These results compliment those obtained with KT5720 (Fig. 6) and confirm that cAMP regulates bradykinininduced $\mathrm{Ca}$ influx through activation of PKA.

Down-stream signaling effects of $\alpha_{s Q 227 L}$ and $\alpha_{i l Q 204 L}$ in MCT cells. To determine if the altered Ca influx pathways in MCT cells expressing mutant $\alpha$ chains have physiologically significant effects on the cells, we studied induction of c-fos mRNA by bradykinin. In a number of systems, induction of c-fos is partially dependent on extracellular $\mathrm{Ca}$ and consequently can serve as a downstream marker for Ca signals $(37,38)$. In MCT cells ionomycin stimulates c-fos expression, so in these cells, a rise in intracellular $\mathrm{Ca}$ is sufficient to activate the c-fos gene 


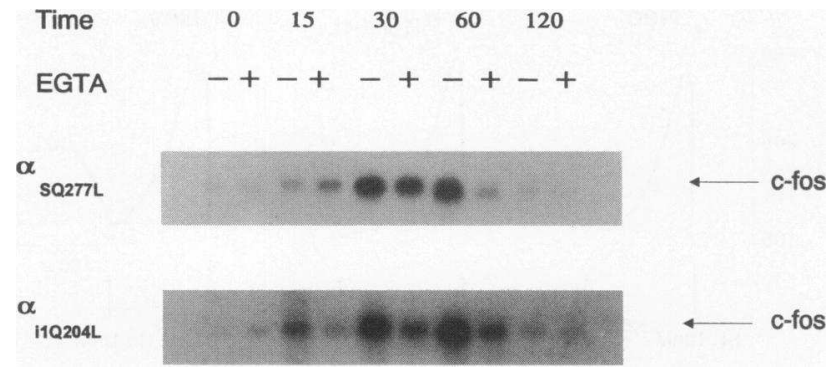

Figure 8. Bradykinin stimulation of c-fos expression in cells expressing $\alpha_{\mathrm{sQ227 \textrm {L }}}$ and $\alpha_{\mathrm{ilQ204L}} \cdot 10-\mathrm{cm}$ dishes of serum-deprived MCT cells were treated with $2 \mathrm{mM}$ EGTA or water $5 \mathrm{~min}$ before the addition of bradyki$\operatorname{nin}\left(10^{-8} \mathrm{M}\right)$. At the time points indicated, medium was removed and total RNA was prepared. $10 \mu \mathrm{g}$ of total RNA was size-fractionated on a formaldehyde-agarose gel, transferred to a nylon filter, and hybridized to a probe for c-fos. Similar results were obtained in three separate experiments.

(data not shown). Fig. 8 shows the time course of c-fos mRNA induction by bradykinin without and with EGTA in MCT cells expressing $\alpha_{\mathrm{sQ227L}}$ and $\alpha_{\mathrm{ilQ} 204 \mathrm{~L}}$. c-fos induction by bradykinin is reduced by pretreatment with $1 \mathrm{mM}$ EGTA, indicating that as in other systems, induction of c-fos by substances like bradykinin is partially dependent on extracellular $\mathrm{Ca}$. In both cell lines, maximum induction occurs at $60 \mathrm{~min}$, but the induction is greater in the cells expressing $\alpha_{\mathrm{ilQ} 204 \mathrm{~L}}$, the cell line with the greatest $\mathrm{Ca}$ influx after a bradykinin stimulus. Equal amounts of RNA were loaded in each lane, and the loading was verified by ethidium bromide staining of the ribosomal bands and hybridization with a probe for GAPDH. Both blots were processed, hybridized, and exposed at the same time under the same conditions. These studies demonstrate that altered $\mathrm{Ca}$ influx at the cell membrane due to increased or decreased adenylyl cyclase can affect signaling at the level of transcription.

\section{Discussion}

Expression of mutant $\alpha$ chains. We used mutant, GTPase-deficient forms of $\alpha_{\mathrm{s}}$ and $\alpha_{\mathrm{i} 1}$ to activate and study signaling pathways that regulate adenylyl cyclase and intracellular $\mathrm{Ca}$ in renal epithelial cells. We chose an expression system that would not lead to high level expression of the mutant proteins out of concern for possible loss of specificity. Although significant levels of protein are produced with the metallothionein vector, we expect that they are lower than would have been achieved with viral or retroviral promoter-based expression systems. Loss of specificity due to high levels of protein expression was observed with overexpression of M2 muscarinic receptors in Chinese hamster ovary cells $(39,40)$. The $\alpha$ chains are active (in the GTP-bound conformation) under the conditions normally found in cells, whereas the endogenous $\alpha$ chains are not (15, $17,26,27,31,32)$. The fact that both mutant $\alpha$ chains have a significant spontaneous rate of guanine nucleotide exchange and minimal GTPase activity makes their activation independent of receptor coupling $(41,42)$. The expression of novel mRNAs and the increase in $\alpha_{\mathrm{s}}$ or $\alpha_{\mathrm{i}}$ antigen over endogenous antigen detected by immunoblotting demonstrate that the cells express proteins with the appropriate biochemical characteristics for constitutively active $\mathrm{G}$ protein $\alpha$ chains.

Regulation of adenylyl cyclase by mutant $\alpha$ chains. The results of these studies indicate that expression of a mutant, activated form of $\alpha_{i 1}$ in a renal epithelial cell line inhibits forskolin-sensitive adenylyl cyclase in MCT cells. Expression of a mutant-activated form of $\alpha_{\mathrm{s}}$ stimulates adenylyl cyclase in these cell types. In MCT cells, hormone-sensitive inhibition of adenylyl cyclase is mediated by pertussis toxin substrates $\left(\alpha_{\mathrm{i} 2}\right.$ or $\alpha_{\mathrm{i} 3}$ ), but neither expresses $\alpha_{\mathrm{i} 1}$.

Although mRNA for types IV, V, and VI adenylyl cyclases, and presumably the corresponding proteins are expressed in whole kidney, their cell-type specific expression in the kidney and renal cell lines is not defined $(8,43-46)$. Additional forms of adenylyl cyclase may also be identified. Consequently, the form or forms of adenylyl cyclase regulated in these studies are not known at this point. Biochemical studies demonstrate variability among adenylyl cyclase isoforms with respect to regulation by $\beta \gamma$ subunits $(5,7,8)$. The present studies demonstrate that adenylyl cyclase isoforms present in MCT cells are regulated in a manner similar to that previously demonstrated in fibroblasts $(26,27,31,32)$.

Inhibition of cAMP accumulation by the normal hormonal mechanisms of these cells and the mutant $\alpha_{\mathrm{i}}$ are not additive indicating that the mechanism of adenylyl cyclase inhibition by $\alpha_{\mathrm{ilQ204L}}$ and the endogenous mechanism of MCT cells is the same. These results are consistent with those from other studies, including those using purified proteins $(26,27,47)$. In the present studies, pertussis toxin treatment of cells blocks bradykinin-induced inhibition of forskolin-stimulated adenylyl cyclase, but has no effect on inhibition of adenylyl cyclase by $\alpha_{\mathrm{ilQ} 204 \mathrm{~L}}$. This result is expected because pertussis toxin blocks the ability of $\alpha \beta \gamma$ heterotrimers to interact with receptors, but would not be expected to influence receptor-independent guanine nucleotide exchange or effector interactions. Although recombinant, myristoylated $\alpha_{\mathrm{iQ} 204 \mathrm{~L}}$ is a pertussis toxin substrate in the presence of $\beta \gamma$ subunits in vitro, the efficiency with which it is labeled with respect to the wild-type protein and whether it is a substrate in vivo is not known (Taussig, R., and A. Gilman, personal communication). Consequently, the reason for the lack of an effect of pertussis toxin in the $\alpha_{\mathrm{ilQ} 204 \mathrm{~L}}$-expressing cells is not defined at this point.

Regulation of intracellular Ca by mutant $\alpha$ chains. In bradykinin-stimulated cells, the mutant $\alpha$ chains affect $\mathrm{Ca}$ influx in a manner that correlates inversely with cAMP production. The presence of $\alpha_{\mathrm{sQ227L}}$, which increases cAMP production in MCT cells, reduces Ca influx, whereas the presence of $\alpha_{\mathrm{ilQ} 204 \mathrm{~L}}$, which reduces cAMP production, increases $\mathrm{Ca}$ influx. The studies presented in this manuscript demonstrate that the adenylyl cyclase system acting through PKA is responsible for these observations rather than a direct interaction of $\alpha$ chains or cAMP with the $\mathrm{Ca}$ influx pathway. $\mathrm{Ca}$ influx in bradykinin-stimulated cells is reduced by stimulation of the adenylyl cyclase system through expression of the mutant activated $\alpha_{\mathrm{s}}$ or the addition of isoproterenol, forskolin, or db-cAMP. Ca influx is increased by reduction of adenylyl cyclase activity through expression of $\alpha_{\mathrm{ilQ} 204 \mathrm{~L}}$ or reduction in PKA activity by treatment with a PKA inhibitor or expression of PKA regulatory subunit with reduced affinity for cAMP. The expressed $\alpha$ chains, isoproterenol, forskolin, cAMP analogues, and inhibition of PKA do not affect bradykinin-induced $\mathrm{Ca}$ release from intracellular stores or $\mathrm{IP}_{3}$ levels.

$\mathrm{Ca}$ influx is not altered by the presence of the mutant $\alpha$ chains unless the cells are stimulated by bradykinin (Fig. 3), demonstrating that changes in adenylyl cyclase activity alone are not sufficient to explain these observations. The fact that 
stimulation with bradykinin is required to see differences in $\mathrm{Ca}$ influx in the three cell lines indicates that the adenylyl cyclase system is regulating the capacitance or refilling $\mathrm{Ca}$ influx pathway. The bradykinin-dependent $\mathrm{Ca}$ influx pathway in MCT cells is blocked by $\mathrm{Ni}$ and $\mathrm{La}$, a characteristic of the "refilling" pathway (15) (Miller, R. T., and K. Kitamura, unpublished observations). Consequently, some component of the signal generated by bradykinin is a prerequisite for alteration of $\mathrm{Ca}$ influx by the cAMP pathway. The potential regulators of $\mathrm{Ca}$ influx include $\mathrm{IP}_{3}, \mathrm{Ca}$, kinases, NO, cGMP, or calcium influx factor (CIF) $(13,48-52)$. A recent report shows that in endothelial cells cholera toxin reduces NO-stimulated cGMP production (53). A consequence of this mechanism could be reduced $\mathrm{Ca}$ influx after bradykinin stimulation of endothelial cells. These studies suggest that the adenylyl cyclase system is not acting on intracellular Ca release or $\mathrm{IP}_{3}$ production but may be acting on the generators or targets of these other potential regulators of $\mathrm{Ca}$ influx or the influx channel.

The $\mathrm{Ca}$ and cAMP signaling systems interact in a number of cell types, the cell type determining the nature of the interaction. In cardiac myocytes, the two systems converge at the Ca channel and act synergistically to increase the inotropic and chronotropic state of the myocardium $(10,11,54)$. In contrast, in the collecting duct of the kidney, the actions of vasopressin to stimulate water and $\mathrm{Na}$ transport through increases in cAMP are antagonized by substances such as $\mathrm{PGE}_{2}$, acetylcholine, and bradykinin, which stimulate $\mathrm{IP}_{3}$ production and raise intracellular Ca (55). However, in the collecting duct, the antagonism does not appear to be at the level of $\mathrm{Ca}$ influx. In the present studies, the cAMP system modulates $\mathrm{Ca}$ influx in MCT cells after stimulation by agonists that stimulate PI turnover and intracellular Ca release.

Many receptor ligands including bradykinin, acetylcholine, and serotonin simultaneously stimulate $\mathrm{IP}_{3}$ production with intracellular $\mathrm{Ca}$ release and inhibit adenylyl cyclase. Interaction of the adenylyl cyclase and Ca signaling systems such as described in this report could modulate $\mathrm{Ca}$-dependent signals in two ways. In the first, the rapid phospholipase $\mathrm{C}$-dependent rise in intracellular $\mathrm{Ca}$ from intracellular stores and the sustained phase of intracellular $\mathrm{Ca}$ elevation after phospholipase $\mathrm{C}$ activation could be regulated independently. In the presence of bradykinin alone, phospholipase $\mathrm{C}$ would be activated and adenylyl cyclase would be inhibited, providing a maximal intracellular Ca signal. Substances that act through $\alpha_{\text {s }}$ would reduce the prolonged intracellular $\mathrm{Ca}$ elevation without altering the initial portion of the signal. This scenario is supported by the results obtained with bradykinin-induced c-fos expression in MCT cells expressing $\alpha_{\mathrm{sQ227L}}$ and $\alpha_{\mathrm{ilQ} 204 \mathrm{~L}}$.

A second function of the interaction between these two signaling systems could be to modulate the strength of successive Ca-dependent signals. The rate of $\mathrm{Ca}$ influx correlates with $\mathrm{Ca}$ release from intracellular stores in most cell systems (13, 15 ). This correlation presumably exists so that signals can be repeated with the same strength. In MCT cells in the presence of activators of adenylyl cyclase, $\mathrm{Ca}$ influx is reduced and presumably so is the refilling of intracellular stores. Consequently, to the extent that subsequent signals that depend on Ca release from intracellular stores require refilling of those stores, they will be weaker in the presence of elevated levels of cAMP.

These studies demonstrate that the $\mathrm{Ca}$ influx pathway in MCT cells can act as a "signal integrator" for signals generated by the $\mathrm{IP}_{3}$ /intracellular $\mathrm{Ca}$ and adenylyl cyclase systems. The adenylyl cyclase system acting through cAMP-dependent kinase, modulates $\mathrm{Ca}$-dependent signals by altering $\mathrm{Ca}$ influx after stimulation by bradykinin. Activation of adenylyl cyclase reduces the sustained phase of the bradykinin-induced Ca signal, whereas inhibition of adenylyl cyclase enhances it. The physiologic effects of this system are demonstrated by the enhanced ability of bradykinin to stimulate $\mathrm{c}$-fos expression in the cells with increased bradykinin-induced Ca influx $\left(\alpha_{\mathrm{ilQ204L}}\right)$ and the reduced ability of bradykinin to stimulate $c$ - $f o s$ expression in cells with reduced bradykinin-induced Ca influx $\left(\alpha_{\mathrm{sQ227L}}\right)$.

\section{Acknowledgments}

The author thanks Paul McLeroy for expert technical assistance; Paul Sternweis, Orson Moe, Bruce Stanton, and Robert Alpern for helpful discussions; Susanne Mumby for supplying antibodies used in immunoblotting; Eric Neilson for supplying MCT cells; Stan McKnight for supplying the Zem-228 expression vector; Randall Reed for supplying $\mathrm{G}$ protein $\alpha$ chain cDNAs; Shmuel Muallem for help with the intracellular Ca studies; and Dr. Donald Seldin and Dr. Daniel Foster for persistent encouragement.

This work was supported by grants from the National Institutes of Health (DK-41726, and DK-39298).

\section{References}

1. Birnbaumer, L., J. Codina, R. Mattera, A. Yatani, N. Scherer, M.-T. Toro, and A. M. Brown. 1987. Signal transduction by G proteins. Kidney Int. 32(Suppl. 23):S14-S37.

2. Gilman, A. G. 1987. G proteins: transducers of receptor-generated signals. Annu. Rev. Biochem. 56:615-649.

3. Premont, R. T., O. Jacobowitz, and R. Iyengar. 1992. Lowered responsiveness of the catalyst of adenylyl cyclase to stimulation of $G_{s}$ in heterologous desensitization: a role for adenosine 3' 5 '-monophosphate-dependent phosphorylation. Endocrinology. 131:2774-2784.

4. Stryer, L., and H. R. Bourne. 1986. G proteins: a family of signal transducers. Annu. Rev. Cell Biol. 2:391-419.

5. Federman, A. D., B. R. Conklin, K. A. Schrader, R. R. Reed, and H. R. Bourne. 1992. Hormonal stimulation of adenylyl cyclase through $\mathrm{G}_{i}$ protein $\beta \gamma$ subunits. Nature (Lond.). 356:159-160.

6. Neer, E. J., and D. E. Clapham. 1988. Roles of G protein subunits in transmembrane signalling. Nature (Lond.). 333:129-134.

7. Tang, W-J., and A. G. Gilman. 1991. Type-specific regulation of adenylyl cyclase by $\mathrm{G}$ protein $\beta \gamma$ subunits. Science (Wash. DC). 254:1500-1503.

8. Tang, W-J., and A. G. Gilman. 1992. Adenylyl cyclases. Cell. 70:869872.

9. Simon, M. I., M. P. Strathman, and N. Gautam. 1991. Diversity of G protein signal transduction. Science (Wash. DC). 252:802-808

10. Yatani, Y., J. Codina, Y. Imoto, J. P. Reeves, L. Birnbaumer, and A. M. Brown. 1987. A G protein directly regulates mammalian cardiac calcium channels. Science (Wash. DC). 238:1288-1292.

11. Brown, A. M., and L. Birnbaumer. 1988. Direct G protein gating of ion channels. Am. J. Physiol. 254 (Heart Circ. Physiol. 23): H401-H410.

12. Ross, E. M. 1989. Signal sorting and amplification through $G$ proteincoupled receptors. Neuron. 3:141-152.

13. Berridge, M. J. 1993. Inositol trisphosphate and calcium signalling. Nature (Lond.). 361:315-325.

14. Muallem, S. 1990. Calcium transport by resting and stimulated cells. Intracellular Calcium Regulation. Alan R. Liss, New York, 349-380.

15. Tsien, R. W., and R. Y. Tsien. 1990. Calcium channels, stores, and oscillations. Annu. Rev. Cell Biol. 6:715-760.

16. Graziano, M. P., and A. G. Gilman. 1989. Synthesis in Escherichia coli of GTPase-deficient mutants of $\mathrm{G}_{\mathrm{s} \alpha}$. J. Biol. Chem. 264:15475-15482.

17. Masters, S. B., R. T. Miller, M. Chi, F. Chang, B. Beiderman, N. G. Lopez, and H. R. Bourne. 1989. Mutations in the GTP-binding site of $\mathrm{G}_{\mathrm{s} \alpha}$ alter stimulation of adenylyl cyclase. J. Biol. Chem. 264:15467-15474.

18. Haverty, T. P., C. J. Kelly, W. H. Hines, P. S. Amenta, M. Watanabe, R. A. Harper, N. A. Kefalides, and E. G. Neilson. 1988. Characterization of a renal tubular epithelial cell line which secretes the autologous target antigen of autoimmune experimental interstitial nephritis. J. Cell Biol. 107:1359-1368.

19. Jones, D. T., and R. R. Reed. 1987. Molecular cloning of five GTP binding protein cDNA species from rat olfactory neuroepithelium. J. Biol. Chem. 262:14241-14249. 
20. Sambrook, J., E. F. Fritsch, and T. Maniatis. 1989. Molecular Cloning, A Laboratory Manual. 2nd ed. Cold Spring Harbor Laboratory, Cold Spring Harbor, NY.

21. Clegg, C. H., L. A. Correll, G. G. Cadd, and G. S. McKnight. 1987. Inhibition of intracellular c-AMP-dependent protein kinase using mutant genes of the regulatory type I subunit. J. Biol. Chem. 262:13111-13119.

22. Lowry, O. H., N. J. Rosebrough, A. L. Farr, and R. J. Randall. 1951. Protein measurement with the Folin phenol reagent. J. Biol. Chem. 193:265-275.

23. Casey, P. J., H. K. W. Fong, M. I. Simon, and A. G. Gilman. 1990. G a guanine nucleotide-binding protein with unique biochemical properties. J. Biol. Chem. 65:2383-2390.

24. Fort, P., L. Marty, M. Piechacyzk, S. El Sabrouty, C. Dani, P. Jeanteur, and J. M. Blanchard. 1985. Various rat adult tissues express only one major mRNA species from the glyceraldehyde-3-phosphate-dehydrogenase multigene family. Nucleic Acids Res. 13:1431-1441.

25. Curran, T., M. B. Gordon, K. L. Rubino, and L. C. Sambucetti. 1987. Isolation and characterization of the c-fos (rat) cDNA and analysis of post-translational modifications in vitro. Oncogene. 2:79-84.

26. Wong, Y. H., A. Federman, A. M. Pace, I. Zachary, T. Evans, J. Pouyssegur, and H. R. Bourne. 1991. Mutant $\alpha$ subunits of $\mathrm{G}_{\mathrm{i} 2}$ inhibit cyclic AMP accumulation. Nature (Lond.). 351:63-65.

27. Wong, Y. H., B. R. Conklin, and H. R. Bourne. 1992. $G_{z}$-mediated hormonal inhibition of cyclic AMP accumulation. Science (Wash. DC). 255:339$341,1992$.

28. Saloman, Y., C. Londos, and M. Rodbell. 1974. A highly sensitive adenylate cyclase assay. Anal. Biochem. 58:541-552.

29. Muallem S, M. Khademazad, G. Sachs. 1990. The route of $\mathrm{Ca}^{2+}$ entry during reloading of the intracellular $\mathrm{Ca}^{2+}$ pool in pancreatic acinar cells. J. Biol. Chem. 265:2011-2016.

30. Grynkiewicz, G., M. Poenie, and R. Y. Tsien. 1985. A new generation of $\mathrm{Ca}^{2+}$ indicators with greatly improved fluorescence properties. J. Biol. Chem. 260:3440-3450.

31. Hermouet, S., J. J. Merendino, Jr., J. S. Gutkind, and A. M. Spiegel. 1991 Activating and inactivating mutations in the $\alpha$ subunit of $\mathrm{Gi}_{2}$ protein have opposite effects on proliferation of NIH 3T3 cells. Proc. Natl. Acad. Sci. USA. 88:1045510459.

32. Lowndes, J. M., S. K. Gupta, S. Osawa, and G. L. Johnson. 1991. GTPasedeficient $\mathrm{G}_{\alpha \mathrm{i} 2}$ oncogene gip2 inhibits adenylyl cyclase and attenuates receptorstimulated phospholipase $A_{2}$ activity. J. Biol. Chem. 266:14193-14197.

33. Bourne, H. R., D. A. Sanders, and F. McCormick. 1990. The GTPase superfamily: a conserved switch for diverse cell functions. Nature (Lond.). 348:125-131.

34. Birnbaumer, L. 1990. Transduction of receptor signal into modulation of effector activity by $G$ proteins: the first 20 years or so. . . FASEB (Fed. Am. Soc. Exp. Biol.) J. 4:3068-3078.

35. Aboolian, A., and E. P. Nord. 1988. Bradykinin increases cytosolic free $\left[\mathrm{Ca}^{2+}\right]$ in proximal tubule cells. Am. J. Physiol. 255 (Renal Fluid and Electrolyte Physiol. 24):F486-F493.

36. Kase, H., K. Iwahashi, S. Nakanishi, Y. Matsuda, K. Yamada, M. Takahashi, C. Murakata, A. Sato, and M. Kaneko. 1987. K-252 compounds, novel and potent inhibitors of protein kinase $\mathrm{C}$ and cyclic nucleotide-dependent protein kinases. Biochem. Biophys. Res. Commun. 142:436-440.

37. Bading, H., D. D. Ginty, and M. E. Greenberg. 1993. Regulation of gene expression in hippocampal neurons by distinct calcium signalling pathways. Science (Wash. DC). 260:181-186.
38. Trejo, J., and J. H. Brown. 1991. c-fos and c-jun are induced by muscarinic receptor activation of protein kinase $\mathrm{C}$ but are differentially regulated by intracellular calcium. J. Biol. Chem. 266:7876-7882.

39. Ashkenazi, A., J. W. Winslow, E. G. Peralta, G. L. Peterson, M. I. Schimerlik, D. J. Capon, and J. Ramachandran. 1987. An M2 muscarinic receptor subtype coupled to both adenylyl cyclase and phosphoinositide turnover. Science (Wash. DC). 238:72-675.

40. Peralta, E. G., A. Ashkenazi, J. W. Winslow, J. Ramachandran, and D. J. Capon. 1988. Differential regulation of PI hydrolysis and adenylyl cyclase by muscarinic receptor subtypes. Nature (Lond.). 334:434-437.

41. Carty, D. J., E. Padrell, J. Codina, L. Birnbaumer, J. D. Hildebrandt, and R. Iyengar. 1990. Distinct guanine nucleotide binding and release properties of the three $G_{i}$ proteins. J. Biol. Chem. 265:6268-6273.

42. Linder, M. E., D. A. Edward, R. J. Miller, and A. G. Gilman 1990. Purification and characterization of $G_{\alpha \alpha}$ and three types of $G_{i \alpha}$ after expression in Escherichia coli. J. Biol. Chem. 265:8243-8251.

43. Feinstein, P. G., K. A. Schrader, H. A. Bakalyar, W.-J. Tang, J. Krupinski, A. G. Gilman, and R. R. Reed. 1991. Molecular cloning and characterization of a $\mathrm{Ca}^{2+} /$ calmodulin-insensitive adenylyl cyclase from rat brain. Proc. Natl. Acad. Sci. USA. 88:10173-10177.

44. Gao, B., and A. G. Gilman. 1991. Cloning and expression of a widely distributed (type IV) adenylyl cyclase. Proc. Natl. Acad. Sci. USA. 88:1017810182.

45. Katsushika, S., L. Chen, J.-I. Kawabe, R. Nilakantan, N. J. Hanlon, C. J. Homcy, and Y. Ishikawa. 1992. Cloning and characterization of a sixth adenyly cyclase isoform: types $\mathrm{V}$ and VI constitute a subgroup within the mammalian adenylyl cyclase family. Proc. Natl. Acad. Sci. USA. 89:8774-8778.

46. Premont, R. T., J. Chen, H.-W. Ma, M. Ponapalli, and R. Iyengar. 1992. Two members of a widely expressed subfamily of hormone-stimulated adenyly cyclases. Proc. Natl. Acad. Sci. USA. 89:9809-9813.

47. Katada, T., J. K. Northup, G. M. Bokoch, M. Ui, and A. G. Gilman. 1984 The inhibitory guanine nucleotide-binding regulatory component of adenylate cyclase. J. Biol. Chem. 59:3578-3585

48. Bahnson, T. D., S. J. Pandol, and V. E. Dionne. 1993. Cyclic GMP modulates depletion-activated $\mathrm{Ca}$ entry in pancreatic acinar cells. 1993. J. Biol. Chem. 268:10808-10812.

49. Berridge, M. J. A tale of two messengers. 1993. Nature (Lond.). 365:388389.

50. Clapham, D. E. A mysterious new influx factor? 1993. Nature (Lond.) 364:763-764.

51. Parkeh, A. B., H. Terlau, and W. Stuhmer. 1993. Depletion of InsP $P_{3}$ stores activates a $\mathrm{Ca}$ and $\mathrm{K}$ current by means of a phosphatase and diffusible messenger. Nature (Lond.). 364:814-818.

52. Randriamampita, C., and R. Y. Tsien. 1993. Emptying of intracellular Ca stores releases a novel small messenger that stimulates Ca influx. Nature (Lond.). 364:809-814.

53. Gil-Longo, J., M. N. Dufour, G. Guillon, and C. Lugnier. 1993. G proteins in aortic endothelial cells and bradykinin-induced formation of nitric oxide. Eur. J. Pharmacol. Mol. Pharmacol. Sect. 247:119-125.

54. Mery, P.-F., V. Brechler, C. Pavoine, F. Pecker, and R. Fischmeister. 1990. Glucagon stimulates the cardiac $\mathrm{Ca}^{2+}$ current by activation of adenylyl cyclase and inhibition of phosphodiesterase. Nature (Lond.). 345:158-161.

55. Breyer, M. D. 1991. Regulation of water and salt transport in collecting duct through calcium-dependent signalling mechanisms. Am. J. Physiol. 260 (Renal Fluid Electrolyte Physiol. 29):F1-F11. 